\title{
The issue of sport specialization and the development of sport expertise
}

\author{
Linda Komínková, Tomáš Perič \\ Faculty of Physical Education and Sport, Charles University, Prague
}

\begin{abstract}
There are two different ways how to achieve sport expertise. First is called "early sport specialization" and second is called "early sport sampling". Although, early sport specialization is associated with negative physical, psychological and social development consequencies, researches claim that early specialized approach to sports training is necessary to achieve elite sport performance because of 10.000 hour rule and the theory of deliberate practice. On the other hand, experts who defend early sampling approach argue that sampling various sports during childhood and later start with special training is the basis for specialization in adolescence and adulthood and that athlete can benefit from such a transfer across sports.

The aim of this review is to discuss early sport specialization and early sport sampling approach in term of expertise development in sport.

Results suggest that despite a relatively high number of research in this area, it is still not clear which approach is more effective for attaining sport expertise. Conclusions of studies that examined the validity of the theory of deliberate practice and 10.000 hour rule in different sports are inconsistent. In addition, studies that dealt with early sampling approach examined mainly team sports and were conducted with retrospective design in which athletes do not have to recall their experiences or that the recall of experiences can be biased. Moreover, very few studies report early specialization of their athletes. Therefore, longitudinal studies are needed to reveal which approach is more effective to achieve expertise in sport.
\end{abstract}

Keywords: early sport specialization, early sampling (diversification), sport expertise, deliberate practice, deliberate play

\section{INTRODUCTION}

In the 1950s was early sport specialization considered the most effective way to achieve expertise in sport. It was expected that early specialized athletes will continue to improve their sport performance (Valik, 1974). However, this assumption was wrong. In the 1980s, research has shown that early sport specialization does not ensure elite sport performance (Matvejev, 1981).

Although, the issue of early sport specialization is discussed since 1970s (Valik, 1974), it is still current topic. This is evidenced by the number of published articles, especially review articles which deal with positive and negative aspects of early sport specialization (e.g. Sluder et al., 2017; Myer et al., 2015; Baker et al., 2009). These reviews generally concludes, that due to the number of negative physical and psychosocial consequences, early specialization in sport is inappropriate way to achieve elite sport performance.

However, researches who support the concept of early sport specialization have a strong argument for early sport specialization. They claim that early specialization is important for future success because the earlier one starts adhering to a strict training regime; the quicker one will attain desired level of skill. More specifically, someone starting a deliberate practice routine at a later age would be unable to "catch up" to a performer who started earlier, all other things being equal (Baker, Cobley \& Fraser-Thomas, 2009). 
On the other hand, researches introduced another approach to long-term athlete development. This approach is called early sport sampling or early diversification (Goodway \& Robinson, 2015). In this approach, the so-called transfer of skills is highlighted because there is a general assumption that athletes can benefit from this transfer across sports (Williams \& Ford, 2008).

In this review, we deal with the question of whether early sport specialization or early sport sampling is necessary for development of sport expertise. According to Starkes et al. (2003), we understand the concept of sport expertise as the result of four domains. These domains are physiological, technical, cognitive and emotional. While this article focuses mainly on the technical domain of sport expertise that is associated with skill acquisition in sport.

\section{METHODS}

The aim of this review is to discuss early sport specialization and early sampling approach in term of expertise development in sport. We used PRISMA to create basic guidelines (Moher et al., 2011). The review methodology itself consists of four steps (see schema 1).

We searched articles in these databases: EBSCOhost (SPORTDiscus with Full Text), MEDLINE, and Google Scholar. We have included the literature published in the period 1990-2018.

We used following terms for the search: early sport specialization, late sport specialization, sport expertise. Articles were selected if they met these criteria: (1) the article was published in the years 1990-2018, (2) the article contained at least one reference to early or late sport specialization and expertise development in sport, either in the title or in abstract or in set of keywords, (4) the article was written in English.

These conditions met as of December 31, 2018 a total of 159 articles. Subsequently, the titles and abstracts of the articles were read. If the article did not meet the essential requirements, it was found to be inappropriate for this type of review. After this "shallow" reading, 55 articles were selected, both quantitative and qualitative studies.

These 55 articles went through a detailed study. 19 articles were removed for failing to meet the above criteria. Therefore, a total of 36 texts were used.

Searching in databases: According to given criteria we searched for $n=159$ articles (after removing duplicates)

\begin{tabular}{|c|}
\hline$\downarrow$ \\
\hline "Shallow" reading of articles: after this step, $\mathrm{n}=55$ articles were left \\
\hline$\downarrow$ \\
\hline $\begin{array}{l}\text { Detailed study of articles: } 19 \text { articles were not suitable according } \\
\text { to a comprehensive analysis }\end{array}$ \\
\hline$\downarrow$ \\
\hline
\end{tabular}

Schema 1: The article search procedure 


\section{RESULTS}

\section{Early sport specialization}

Early sport specialization is usually described as athletes limiting participation to a single sport on a year-round basis at the exclusion of other sport or nonsport activities (Ericsson et al., 1993; Wiersma, 2000; Ferguson \& Stern, 2014; Myer et al., 2016).

Côté, Lidor and Hackfort (2009) define early sport specialization as a focused involvement in one sport and a large number of hours of deliberate practice with the goal of improving sport skills and performance outcomes during childhood.

According to Baker, Cobley and Fraser-Thomas (2009) early sport specialization includes four specific parameters: early start age in sport; early involvement in one sport (as opposed to participating in several sports); early involvement in focused, high intensity training; and early involvement in competitive sport.

These definitions mentioned above are very similar. However, the main common point for those who defend early sport specialization is that early start of special and intense training distinguishes future professionals from amateurs (Côté, Lidor \& Hackfort, 2009).

There are terms that are closely related to early sport specialization: 10.000 hour rule, the power law of practice and the theory of deliberate practice.

\subsection{0 hour rule}

Ericsson (1993) investigated what factors helped predict expert performance. His results stated that high volumes of deliberate practice (defined as specific, focused, skill based practice) at a very young age was the strongest predictor of becoming an expert performer.

This study leads to the famous " 10.000 hour rule". Specifically, beginning a task at a very young age (before age 5-7) and acquiring high volumes of deliberate practice (5.000-10.000 hours) resulted in the likelihood of an individual becoming an expert (Ferguson \& Stern, 2014). It means more than 3 hours of training or competing daily for ten years (Perič \& Pecha, 2014).

\section{The power law of practice}

Research examining the accumulated effects of prolonged practice and the rate of learning has robustly indicated that performance increases monotonically according to a power function. The power law of practice states that learning occurs at a rapid rate after the onset of practice but that this rate of learning decreases over time as practice continues (Baker, 2003). In other words, the more time individuals devote to practice, the greater their level of achievement but the more difficult it becomes to make further improvements (Perič \& Pecha, 2014).

\section{Theory of deliberate practice}

The theory of deliberate practice developed by Ericsson and colleagues (1993; Ericsson \& Charness, 1994) advanced the general concept of expertise development through focused training over time with one major stipulation. They suggested that it was not simply any form of training that differentiated individual performance, but the engagement in a specific form of training they termed "deliberate practice".

By definition, this type of training involved practice activities that were effortful, low in inherent enjoyment, and purposefully designed to address current areas of weakness (Baker, Cobley \& Fraser-Thomas, 2009).

The theory of deliberate practice postulates that experts are always made, not born. If we translate this theory to the youth-sport domain, it means that if athletes want to be high-level performers, they need to deliberately engage in practice during the specialization years, spend- 
ing time wisely and always focus on tasks that challenge current performance (Gonçalves, Rama \& Figueiredo, 2012).

\section{Early sport specialization and development of sport expertise}

However, the theory of deliberate practice according to Ericsson et al. (1993) is valid for other activities, especially for music. Therefore, researchers in the sports domain have been keen to examine the validity of deliberate practice theory and the 10.000 hour rule. Because the answer to the question of whether the high quantity and quality of deliberate practice at a young age is sufficient to achieve a peak performance level is of crucial importance for sports training and talent selection (Ward et al., 2004). The question of importance to performers and practitioners is whether practice alone is enough to attain expertise, and more specifically, to produce improvements in performance (Ward et al., 2004)?

Scientific evidence from different sports supports a positive relationship between practice hours and expertise level (e.g. Helsen et al., 1998; Hodges et al., 2004; Baker et al., 2005). However, the 10.000 hour rule and the theory of deliberate practice some studies in sport confirmed but others refuted. Starkes and colleagues (1996) were the first to undertake work on deliberate practice in sport. Athletes who participated in individual sports reported spending on average more than 10 years in practice before reaching an international level (Ward et al., 2004). Afterwords, Helsen et al. (1998) extended this initial work to team sport athletes by examining the practice histories of international, national, and provincial level soccer players from Belgium. And in a second team-sport domain, they examined the practice habits of players at similar levels of skill in field hockey. In both cases has been confirmed positive relationship between a number of sport-specific practices and the achievement of skill levels.

Nevertheless, some researches claim that 10.000 hours of deliberate practice may not be required to achieve elite performance. For example, Hodges et al. (2004) found that elite triathletes and swimmers trained for more than 10 years, but they did not acumulate 10,000 hour of deliberate practice. Also Baker et al. (2003b) found that elite basketball, football and hockey players did not accumulate 10,000 hours of deliberate practice, although they have been training in their sports for over 11 years as well. Interestingly, some studies confirm that for athletes is deliberate practice fun (Baker \& Young, 2014; Deakin \& Cobley, 2003). This is in contradiction with the definition of deliberate practice by Ericsson et al. (1993).

These findings suggest that the theory of deliberate practice and 10.000 hour rule may not be exactly the same for development of expertise in sport.

\section{Early sampling}

In contrast to early sport specialization, early sampling refers to engaging in a variety of different sports during the formative youth sport years with the ultimate goal of learning skills and having fun (Côté, Lidor \& Hackfort, 2009). In this approach children should learn a broad base of fundamental motor skills before they start to specialize (Goodway \& Robinson, 2015). It favours a focus on involvement in a number of different sports before specializing in later stages of development (Wiersma, 2000).

According to Goodway and Robinson (2015) is early sampling in the formative youth years clearly superior to early sport specialization. Côté, Lidor and Hackfort (2009) claim that early sampling years are considered as essential building blocks for self-regulated investment in elite sport during adolescence and adulthood.

Some authors also use the term "early diversification" as a synonym for "early sampling" (e.g. Baker et al., 2009; Baker, 2003; Côté, Lidor \& Hackfort, 2009).

Nevertheless, in Eastern European literature is used term "age appropriate practice" (Perič \& Pecha, 2014, Dovalil et al., 2002) instead of "early sampling". "Age appropriate practice" is in the formative youth sport years characterized by high amount of so-called "multiside develop- 
ment" which also means that children should engage in a variety of different sports in early stages of sport development.

\section{Deliberate play}

For sampling years is characteristic sampling various sports and also engaging in deliberate play (Côté \& Fraser-Thomas, 2007). Deliberate play is described as engaging in an activity primarily for intrinsic enjoyment, although the activity may still contribute to skill learning (Côté et al., 2007).

According to Baker and Côté (2006), deliberate play is defined as sport activities that are intrinsically motivating and provide gratification and enjoyment, as well as sampling in early years of sport participation may lead to more enjoyment and a lower frequency of dropout, which indirectly contribute to the attainment of a high level of performance in adult years.

The informality of deliberate play allows children to engage in sports with minimal equipment, in any kind of space, with any number of players, and with players of different ages and sizes. This kind of environment is easily created and does not necessarily require characteristics of formal organized sport and structured practice, such as adult supervision, coaches, officials, specialized equipment, time limits, or uniforms (Côté, Lidor \& Hackfort, 2009).

\section{Transfer of skills}

It is hypothesized that experiences in different sports provide the young athlete with important abilities. These abilities prove beneficial in the development of sport-specific skills required to reach elite performance in the main sport at a later stage in the career. Therefore, there is a general assumption that talented athletes can benefit from such a transfer across sports (Williams \& Ford, 2008).

Baker et al. (2003) claim that transfer of learning occurs from one sport to another, including both cognitive and physical abilities. Further, Schmidt and Wrisberg (2000) suggest that the effect of such a transfer is most pronounced during early stages of involvement, which corresponds to the timeframe of the sampling years in the "Developmental Model of Sport Participation" (Côté, Baker \& Abernethy, 2007). Based on these considerations, it can be hypothesized that involvement in different sports, during at least the early stage of the career, may be beneficial for reaching elite performance in certain sports.

Baker, Côté \& Abernethy (2003b) indicated that participation in other relevant activities (e.g. other sports where dynamic decision-making is necessary) during early phases of development augmented the physical and cognitive skills necessary in their primary sport. They have shown that world-class team players that demonstrated greater diversity across several domains had also accrued less practice hours within the specialist domain prior to national selection compared to those who exhibited a less diverse participation profile and were not of world class standing.

Acquired sport skills and physiological changes achieved during early sampling years can transfer to later sport specialization of an athlete. More specifically, athletes gain ancillary benefits via some mechanism of transfer from engagement in nondomain activities requiring similar skills (or at least possessing relevant physical and/or cognitive attributes), to those in their domain of expertise (Baker, Côté \& Abernethy, 2003a).

Greater diversity across sports at an earlier age may manifest itself in more flexible perceptualmotor and perceptual-cognitive solutions to a broader range of existing, as well as novel problems and ultimately, to the attainment of adaptive expertise (Hatano \& Inagaki, 1986).

Current research confirms that the transfer effect is the most significant in early stages of sports training (Schmidt, Wrisberg, 2000; Côté et al., 2012). Therefore, a broad base of fundamental motor skill development that is learned through sport sampling is necessary and important before sport specialization. Thus, sport sampling in the formative youth years is clearly superior 
to early sport specialization (Goodway \& Robinson, 2015). The transfer effect can be considered as the basic principle of early sampling (diversification) approach (Baker et al., 2009).

\section{Early sampling and development of sport expertise}

The "sampling years" were proposed to be a period where deliberate play and diversity were both encouraged and beneficial to the development of skilled performance (Côté, 1999; Côté \& Hay, 2002). A high amount of deliberate play during sampling years establishes a range of motor and cognitive experiences that children can ultimately bring to their principal sport of interest (Côté, Lidor \& Hackfort, 2009).

Several studies of elite athletes have found that elite performance is usually preceded by a period of sampling various sports. Baker, Côté and Abernethy (2003b) through a process of semistructured interviews, retrospectively examined the participation histories of elite players who held an international or world-class ranking in a variety of different team sports. These authors found that expert and world-class athletes engaged in considerably more "deliberate play" during the sampling years (i. e., 7 to 12 years) than non-experts. Vaeyens et. al. (2009) revealed that a higher proportion of the world-class athletes trained and competed in other sports beyond their current individual main sport and they invested significantly more training time in other sports. Ginsburg et al. (2014) found that only $25 \%$ of professional baseball players had specialized in one sport before the age of 12 . Bridge and Toms (2013) found that significantly more high performance athletes in the United Kingdom had competed in multiple sports during their early teens rather than having specialized in only one sport.

Evidence suggests a beneficial effect of early diversification not only on the sport performance but also on other variables. Children who sample multiple sports in early years are more likely to develop competence in the type of object control and locomotor skills that make up many different sports. Therefore, these children will have many different sports available to them across the lifespan (Goodway \& Robinson, 2015).

Because limited skill acquisition during early sport specialization may limit the acquisition of fundamental motor skills. This can negatively affect engaging in sport activities later in adulthood (Wiersma, 2000; Branta, 2010). For example, young children who specialize early in gymnastics will not necessarily develop competence in object control skills (e.g. catching, throwing) and thus they will be less likely to find enjoyment in lifetime sports such as basketball, softball, and tennis (Goodway \& Robinson, 2015). If children develop fundamental motor skill competence through sport sampling, they will be able to apply these fundamental motor skills to many physical activities later in life (Clark \& Metcalfe, 2002).

Further, during early phases of growth and maturation, early sampling may stimulate generic physiological and cognitive adaptations, which lay the groundwork for specialized physical and cognitive capacities necessary for later expertise. Moreover, athletes who sample and diversify in their young years may be at less risk for injuries than their peers that specialized early (Baker \& Côté, 2006).

\section{DISCUSSION}

When discussing early sport specialization and early sport sampling (diversification) in term of expertise development in sport we need to realize, that these approaches are applicable in sports, where peak performance is achieved before adulthood, such us gymnastics or figure skating (Balyi \& Hamilton, 2004) and also in sports where peak performance is achieved in adulthood, such us track and field or sport games (Balyi \& Hamilton, 2004).

However, it is not still clear if early sampling (diversification) approach is beneficial for all these sports. Côté et al. (2009) conclude that early diversification is not beneficial for athletes 
in sports where peak performance occurs before full maturation, as already mentioned above gymnastics. Also Côté, Lidor \& Hackfort (2009) claim that early sampling (diversification) does not hinder elite sport participation in sports where peak performance is reached after maturation. From this, it follows that sports with a focus on different capabilities (physical, technical, tactical) are unique in their career development and should be analyzed separately.

Many studies which dealt with question, which of these two approaches to long term athlete development is more appropriate for acquiring expertise in sport have been conducted with a retrospective design (e.g. Baker, Côté \& Abernethy 2003b; Vaeyens et. al., 2009; Ginsburg et al., 2014). Common for this design is that face methodological risks, namely that athletes cannot recall their experiences or that the recall of experiences could be biased (Moesch et al., 2013). Therefore, we need more longitudinal empirical studies to reveal which approach is more effective to achieve expertise in sport.

Further, there are also practical issues related to early sport specialization and early sampling. Nowadays, children's sport is associated with financial resources as well as family support. If child is engaged in more sport activities, it requires purchase of sports equipment for every sport and payment of membership fees in each sport. Further, it often requires parents' time to bring children to training, wait for them to finish training and then take them home. Therefore, from a financial and time point of view, early sampling (diversification) could be more demanding than early sport specialization.

\section{CONCLUSION}

The purpose of this review was to discuss early sport specialization and early sampling approach in term of expertise development in sport. According to 10.000 hour rule and the theory of deliberate practice (Ericsson et al., 1993; Ericsson \& Charness, 1994) is early sport specialization necessary for development of sport expertise and is considered as a prerequisite for success. Therefore, early sport specialization has its supporters among athletes, coaches and other sport experts. For example, Smith (2015) presents that golfer Tiger Woods, swimmer Michael Phelps or tennis player Serena Williams as successful examples of this training approach. Nowadays, there are also popular books, which highlight the fact that with sufficient experience, patience, happiness and timing, anyone can become a professional athlete (e.g. Zacha, 2013).

However, our review shows that scientific research did not fully confirm the theory of deliberate practice and 10.000 hour rule in sport domain (Hodges et al., 2004; Baker et al., 2003). Moreover, studies confirm that early specialization approach to children sports training could have many negative consequencies in contrast to early sampling (diversification) (Sluder et al., 2017; Myer et al., 2015; Baker et al., 2009). Therefore, sampling various sports during childhood is reccomended as an alternative way to achieve elite sport performance (Goodway \& Robinson, 2015).

As we have already mentioned in the discussion, although there are many studies that deal with early sport specialization or early sport sampling (diversification), we need more longitudinal empirical studies to reveal positive or negative aspects of early specialization or early sampling (diversification).

\section{Referencies}

Baker, J. (2003). Early specialization in youth sport: A requirement for adult expertise? High ability studies, 14(1), 85-94. Baker, J., Cobley, S., Fraser-Thomas, J. (2009). What do we know about early sport specialization? Not much!. High ability studies, 20(1), 77-89.

Baker, J., Côté, J. (2006). Shifting training requirements during athlete development: The relationship among deliberate practice, deliberate play and other sport involvement in the acquisition of sport expertise. In D. Hackfort and G. Tenenbaum (Eds.), Essential processes for attaining peak performance (pp. 93-110). Aachen: Meyer and Meyer 
Baker, J., Côté, J., \& Deakin, J. (2005). Expertise in ultra-endurance triathletes early sport involvement, training structure, and the theory of deliberate practice. Journal of applied sport psychology, 17(1), 64-78.

Baker, J., Côté, J., Abernethy, B. (2003a). Learning from the experts: Practice activities of expert decision makers in sport. Research Quarterly for Exercise and Sport, 74, 342-347.

Baker, J., Côté, J., Abernethy, B. (2003b). Sport-specific practice and the development of expert decision-making in team ball sports. Journal of applied sport psychology, 15(1), 12-25.

Baker, J., Young, B. (2014). 20 years later: deliberate practice and the development of expertise in sport. International Review of Sport and Exercise Psychology, 7(1), 135-157. doi:10.1080/1750984X.2014.896024

Balyi, I., Hamilton, A. (2004). Long-term athlete development: trainability in childhood and adolescence. Olympic Coach, 16(1), 4-9.

Branta, C. F. (2010). Sport specialization: Developmental and learning issues. Journal of Physical Education, Recreation \& Dance, 81(8), 19-28. doi:10.1080/07303084.2010.10 598521

Bridge, M. W., Toms, M. R. (2013). The specializing or sampling debate: A retrospective analysis of adolescent sports participation in the UK. Journal of Sports Sciences, 31(1), 87-96. doi:10.1080/02640414.2012.721560

Clark, J. E., Metcalfe, J. S. (2002). The mountain of motor development: A metaphor. In J. E. Clark \& J. H. Humphrey (Eds.), Motor Development: Research and Reviews (Vol. 2, pp. 163-190). Reston, VA: National Association for Sport and Physical Education.

Côté, J. (1999). The influence of the family in the development of talent in sports The Sports Psychologist, 13, 395-417.

Côté, J. E. A. N., Lidor, R., Hackfort, D. (2009). ISSP position stand: To sample or to specialize? Seven postulates about youth sport activities that lead to continued participation and elite performance. International journal of sport and exercise psychology, 7(1), 7-17.

Côté, J., Baker, J., \& Abernethy, B. (2007). Practice and play in the development of sport expertise. Handbook of sport psychology, 3, 184-202.

Côté, J., Baker, J., Abernethy, B. (2007). Practice and play in the development of sport expertise. Handbook of sport psychology, 3, 184-202.

Côté, J., Fraser-Thomas, J. (2007). Youth involvement in sport. In P. Crocker (Ed.), Sport psychology: A Canadian perspective (pp. 270-298). Toronto: Pearson.

Côté, J., Hay, J. (2002). Children is Involvement in Sport. Psychological foundations of sport. Boston, MA: Allyn \& Bacon.

Côté, J., Murphy-Mills, J., \& Abernethy, B. (2012). The development of skill in sport. In N.J. Hodges \& A.M. Williams (Eds.), Skill acquisition in sport: Research, theory and practice (2nd ed., pp. 269-286). New York, NY: Routledge.

Deakin, J. M., Cobley, S. (2003). A search for deliberate practice: An examination of the practice environments in figure skating and volleyball. In J. Starkes \& K.A. Ericsson (Eds.), Expert performance in sport: Recent advances in research on sport expertise (pp. 115-135). Champaign, IL: Human Kinetics.

Dovalil, J., Choutka, M., Svoboda, B., Hošek, V., Perič, T., Potměšil, J., Bunc, V. (2002). Výkon a trénink ve sportu [Performance and training in sport]. Praha: Olympia.

Ericsson, K. A., Krampe, R. T., Tesch-Römer, C. (1993). The role of deliberate practice in the acquisition of expert performance. Psychological review, 100(3), 363.

Ericsson, K. A., Charness, N. (1994). Expert performance: Its structure and acquisition. The American Psychologist, 49, $725-747$. doi:10.1037/0003-066X.49.8.725

Ferguson, B., Stern, P. J. (2014). A case of early sports specialization in an adolescent athlete. The Journal of the Canadian Chiropractic Association, 58(4), 377.

Ginsburg, R. D., Smith, S. R., Danforth, N., Ceranoglu, T. A., Durant, S. A., Kamin, H., Masek, B. (2014). Patterns of specialization in professional baseball players. Journal of Clinical Sports Psychology, 8(3), 261-275. doi:10.1123/jcsp.2014-0032

Gonçalves, C. E., Rama, L. M., Figueiredo, A. B. (2012). Talent identification and specialization in sport: an overview of some unanswered questions. International Journal of Sports Physiology and Performance, 7(4), 390-393.

Goodway, J. D., Robinson, L. E. (2015). Developmental trajectories in early sport specialization: a case for early sampling from a physical growth and motor development perspective. Kinesiology review, 4(3), 267-278.

Hatano, G. \& Inagaki, K. (1986). Two courses of expertise. In Ward, P., Hodges, N. J., Williams, A. M., \& Starkes, J. L. (2004). 11 Deliberate practice and expert performance. Skill acquisition in sport: Research, theory and practice, 231.

Helsen, W. F., Starkes, J. L., Hodges, N. J. (1998). Team sports and the theory of deliberate practice. Journal of Sport and Exercise Psychology, 20, 12-34.

Hodges, N. J., Kerr, T., Starkes, J. L., Weir, P. L., Nananidou, A. (2004). Predicting performance times from deliberate practice hours for triathletes and swimmers: What, when, and where is practice important? Journal of Experimental Psychology. Applied, 10(4), 219-237. doi:10.1037/1076- 898X.10.4.219 PubMed

Matvejev, L. P., Novikov, A. D. (1981). Teorie a didaktika tělesné výchovy a sportu. Praha: Olympia.

Moesch, K., Hauge, M. L. T., Wikman, J. M., Elbe, A. M. (2013). Making it to the top in team sports: Start later, intensify, and be determined. Talent Development and Excellence, 5(2), 85-100.

Moher, D., Weeks, L., Ocampo, M., Seely, D., Sampson, M., Altman, D. G., Hoey, J. (2011). Describing reporting guidelines for health research: a systematic review. Journal of clinical epidemiology, 64(7), 718-742.

Myer, G. D., Jayanthi, N., Difiori, J. P., Faigenbaum, A. D., Kiefer, A. W., Logerstedt, D., \& Micheli, L. J. (2015). Sport specialization, part I: does early sports specialization increase negative outcomes and reduce the opportunity for success in young athletes?. Sports Health, 7(5), 437-442. 
Myer, G., Jayanthi, N., DiFiori, J., Faigenbaum, A., Kiefer, A., Logerstedt, D., Micheli, L. (2016). Sports specialization, part II: alternative solutions to early sport specialization in youth athletes. Sports Health, 8(1), 65-73.

Perič, T., Pecha, J. (2014). Sportovní příprava dětí - co ovlivňuje kvalitu tréninkového procesu. In: Flemr, L., Němec, J., Novotný, O. (eds.) (2014).Pohybové aktivity ve vědě a praxi. Konferenční sborník. U příležitosti 60 . výročí založení fakulty tělesné výchovy a sportu Univerzity Karlovy v Praze. Karolinum: Praha, s. 465-475.

Schmidt, R. A., Wrisberg, C. A. (2000). Motor learning and performance, a problem-based learning approach. Champaign: Human Kinetics.

Sluder, J. Brandon, Theresa T. Fuller, Stephen G. Griffin A Zachary M. Mccray (2017). Early vs. Late Specialization in Sport. GAHPERD Journal [online], 49(3), 9-15.

Smith, M. M. (2015). Early sport specialization: A historical perspective. Kinesiology Review, 4(3), 220-229.

Starkes, J. L., Ericsson, K. A. (2003). Expert performance in sports: Advances in research on sport expertise. Human Kinetics.

Starkes, J. L., Deakin, J., Allard, F., Hodges, N. J., Hayes, A. (1996). Deliberate practice in sports: What is it anyway? In K. A. Ericsson (Ed.), The road to excellence: The acquisition of expert performance in the arts and sciences, sports, and games (pp. 81-106). Mahwah, NJ: Erlbaum

Vaeyens, R., Güllich, A., Warr, C. R., Philippaerts, R. (2009). Talent identification and promotion programmes of Olympic athletes. Journal of sports sciences, 27(13), 1367-1380.

Valik, B. V. (1975). Trenérům mladých atletů. Atletika do kapsy. Praha: Olympia.

Ward, P., Hodges, N. J., Williams, A. M., Starkes, J. L. (2004). 11 Deliberate practice and expert performance. Skill acquisition in sport: Research, theory and practice, 231.

Wiersma, L. D. (2000). Risks and benefits of youth sport specialization: Perspectives and recommendations. Pediatric Exercise Science, 12, 13-22.

Williams, A. M., Ford, P. R. (2008). Expertise and expert performance in sport. International Review of Sport and Exercise Psychology, 1(1), 4-18.

Zacha, P. (2013). Kamevéda. Díl 1. Jak vychovat šampiona: od okamžiku narození po 1. třídu základní školy: konkrétní zaměření - vrcholový sport. Velké Meziříčí: vlastním nákladem autora. 